\title{
Vibrational spectroscopic, NMR parameters and electronic properties of three 3-phenylthiophene derivatives via density functional theory
}

\author{
Yuan Mei-Rong ${ }^{1,2^{*}}$, Song $\mathrm{Yu}^{1,2}$ and Xu Yong-Jin ${ }^{1,2}$
}

\begin{abstract}
Quantum chemistry calculations have been performed to compute the optimized geometries, vibrational frequencies, and Mulliken Charges at B3LYP/6-31G(d) and B3LYP/6-311++G(d,p) levels for 3-(4-fluorophenyl)thiophene (FPT), 3-(4-nitrophenyl)thiophene (NPT) and 3-(4-cyanophenyl) thiophene (CPT) in the ground state. In addition, the ${ }^{13} \mathrm{C}$ and ${ }^{1} \mathrm{H}$ NMR are calculated by B3LYP/6-311++G(d,p) and B3LYP/6-311++G(2d,2p) methods. The singlet electronic excited state properties of the three compounds were investigated using the time-dependent density functional method (TD-DFT) at the B3LYP/6-311++G(d,p)//TD- B3LYP/6-311++G(d,p) level of theory. The influence of the substituted groups on C9 atom is discussed.
\end{abstract}

Keywords: Thiophene; DFT; Vibrational spectra; NMR analysis; UV-vis spectra

\section{Introduction}

Thiophene is one of the most studied heterocycles: it is easy to process, chemically stable, and its synthetic applications have been a constant matter of investigation for many years (Giovanna et al. 2005). $\pi$-Conjugated polymers and oligomers based on thiophene building blocks are of immense interest in current research due to their interesting electronic and photophysical properties (Kim et al. 2006; Kline et al. 2006; Patra et al. 2011; Zhang et al. 2011; Marsh et al. 2014; Yumura and Yamashita 2014). Recent literature contains numerous reports on the synthesis and properties of molecular systems having thiophene unit (Zhang et al. 2009; Ustamehmetoglu 2014; Dai et al. 2007; Cho et al. 2012; Patil et al. 2011; Balaji et al. 2011). The electronic properties exhibited by the thiophene and polythiophene derivatives have made them important in organic field effect transistors (OFET) (Yang et al. 2005; Mushrush et al. 2003; Osaka et al. 2007), organic light emitting diodes (OLED) (Cicoira et al. 2006; Lim et al. 2013), solar cells (Hara et al. 2003; Cao et al. 2009; Thomas et al. 2008) and supercapacitors (Sivaraman et al.

\footnotetext{
* Correspondence: aimee12121@hotmail.com

'Laboratory of Advanced Energy Storage Materials \& devices, Center for

Advanced Materials \& Biotechnology, Research Institute of Tsinghua University in Shenzhen, Shenzhen 518057, China

${ }^{2}$ Key Laboratory of Electrochemical Energy Storage Devices, Research Institute of Tsinghua University in Shenzhen, Shenzhen 518057, China
}

2013; Yue et al. 2012; Karthikeyan et al. 2012). The electronic properties of thiophene-based materials can be tuned over a wide range through chemical or architecture modification. It includes different substitution at 2, 3 or 4-position of thiophene molecules.

In most cases, the 2 and 5 positions of thiophene are used for the polymerization. The modification of the molecules for special electronic properties is operated on the 3 and 4-positions (Su et al. 2002; Osaka et al. 1997). Poly (3-phenylthiophene) has represented such a purpose. The introduction of a phenyl group into the backbone of polythiophene stabilizes the conjugated $\pi$-bonds system and makes it an attractive low band gap material for the use in supercapacitors (Zhang and Shi 2004). The substitution of fluorophenyl group on $\beta$-position of thiophene can improve the thermal stability of corresponding polymer. Poly (3-(4-fluorophenyl)thiophene) has a potential application in type III supercapacitors with improved both p-doping and n-doping performance (Shen et al. 2005; Wei et al. 2006).

Density functional theory (DFT) approaches, especially those using hybrid functional, have evolved to a powerful and very reliable tool, being routinely used for the determination of various molecular properties ( $\mathrm{Li}$ et al. 2011). B3LYP functional has been shown to provide an excellent compromise between accuracy and computational spectra 
for molecules of large and medium size (Lu et al. 2013; Yanai et al. 2004). To the best of our knowledge, no theoretical work is done on the 3-phenylthiophene derivatives. Therefore, we made an investigation and studied the structure and spectra of the title compounds using the DFT (B3LYP) method. The aim of our work is to compare the different properties among the three compounds which have different functional groups on the 3-phenylthiophene molecules.

\section{Computational methods}

All DFT calculations of the title compounds (Figure 1) were carried out using Gaussian09 program package using default thresholds and parameters (Gaussian 09, Revision D.01 et al. 2009). The ground-state structural geometries were fully optimized at the B3LYP method (Yanai et al. 2004) along with the standard 6-31G(d) and 6-311++G(d,p) basis sets. All the parameters were allowed to relax and all the calculations converged to an optimized geometry which corresponds to a true energy minimum revealed by the lack of imaginary frequencies. Vibration frequencies were calculated by using B3LYP/6-31G(d) and B3LYP/ 6-311++G(d,p) methods (EI-Azhary and Suter 1996). ${ }^{1} \mathrm{H}$ and ${ }^{13} \mathrm{C}$ NMR chemical shifts are calculated with GIAO approach at B3LYP/6-311++G(d,p) level. The obtained chemical shift values are relative to the shielding of tetramethylsilane (TMS) (Wolff and Ziegler 1998). Timedependent density functional theory (TD-DFT) (Jacquemin et al. 2009) calculations of electronic spectra were performed on the optimized structure at B3LYP/6-31++G $(\mathrm{d}, \mathrm{p})$ levels.

\section{Results and discussion}

\subsection{Molecular geometry}

The optimized geometries of the title compounds have been obtained at B3LYP/6-31G(d) and B3LYP/6-311++G $(\mathrm{d}, \mathrm{p})$ levels. Some optimized geometrical parameters are listed in Table 1. To the best of our knowledge, experimental data on the geometric structures of the three title compounds are not available in the literature.

It is noted from Table 1 that the values of optimized geometrical parameters calculated at B3LYP/6-311++G $(\mathrm{d}, \mathrm{p})$ are smaller than that calculated at B3LYP/6-31G(d) level except for the torsion angle of C2-C3-C6-C7. There are little differences on the bond lengths and bond angles among the three title compounds, which indicate that the both the two levels have almost the same calculated accuracy in this system. The $\mathrm{C}-\mathrm{C}$ bond lengths in benzene ring are between 1.362-1.408 $\AA$, which is much shorter than the typical C-C single bond (1.54 $\AA$ ) and longer than the $\mathrm{C}=\mathrm{C}$ double bond (1.34 $\AA$ ) (Margules et al. 1999). For S1-C2 and S1-C5 bonds, calculated carbon sulfur bond lengths are between 1.725-1.736 $\AA$, which are smaller than the bond length of the single C-S bond (1.82 A) (Ikawa and Whalley 1996). For FPT, the C9-F bond length is $1.356 \AA$ at B3LYP/6-311++G(d,p) level. The C9-N and C9-C bond lengths are 1.474 $\AA$ and $1.430 \AA$ for NPT and CPT, respectively, which stay in the normal range. For NPT, the lengths of the two N-O bonds have almost the same value, which shows a good symmetry within the molecule.

The bond angles $\mathrm{C} 2-\mathrm{S}-\mathrm{C} 5$ in the thiophene ring have the value between $91.36^{\circ}-91.46^{\circ}$ for all the three compounds, indicating that the $\mathrm{S}$ atom is of $\mathrm{sp}^{2}$ hybridization

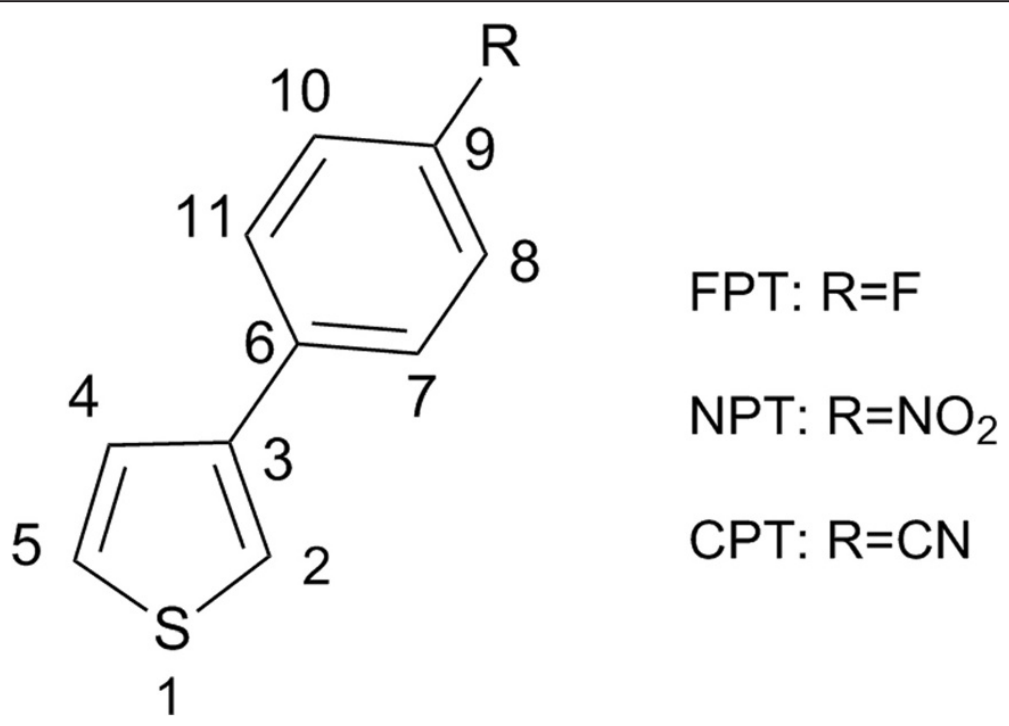

Figure 1 Molecular structures and atom numbering scheme of the title compounds. (3-(4-fluorophenyl)thiophene (FPT), 3-(4-nitrophenyl) thiophene (NPT), 3-(4-cyanophenyl)thiophene (CPT)). 
Table 1 Optimized geometrical parameters of the title compounds, bond lengths $(\AA)$ and bond angles $\left({ }^{\circ}\right)$

\begin{tabular}{|c|c|c|c|c|c|c|}
\hline \multirow[t]{2}{*}{ Parameter } & \multicolumn{2}{|c|}{ FPT } & \multicolumn{2}{|c|}{ NPT } & \multicolumn{2}{|c|}{ CPT } \\
\hline & $6-31 G(d)$ & $6-311++G(d, p)$ & $6-31 G(d)$ & $6-311++G(d, p)$ & $6-31 G(d)$ & $6-311++G(d, p)$ \\
\hline $\mathrm{S1-C2}$ & 1.732 & 1.730 & 1.728 & 1.725 & 1.728 & 1.726 \\
\hline $\mathrm{C} 2-\mathrm{C} 3$ & 1.376 & 1.374 & 1.378 & 1.376 & 1.378 & 1.375 \\
\hline $\mathrm{C} 3-\mathrm{C} 4$ & 1.439 & 1.436 & 1.439 & 1.436 & 1.439 & 1.436 \\
\hline $\mathrm{C} 4-\mathrm{C} 5$ & 1.364 & 1.363 & 1.364 & 1.362 & 1.364 & 1.363 \\
\hline C5-S1 & 1.735 & 1.732 & 1.736 & 1.732 & 1.735 & 1.732 \\
\hline $\mathrm{C} 3-\mathrm{C} 6$ & 1.478 & 1.478 & 1.475 & 1.474 & 1.475 & 1.475 \\
\hline $\mathrm{C} 6-\mathrm{C} 7$ & 1.406 & 1.403 & 1.408 & 1.406 & 1.407 & 1.405 \\
\hline $\mathrm{C} 7-\mathrm{C} 8$ & 1.393 & 1.392 & 1.389 & 1.387 & 1.389 & 1.387 \\
\hline $\mathrm{C8}-\mathrm{CP}$ & 1.390 & 1.386 & 1.394 & 1.392 & 1.405 & 1.403 \\
\hline C9-C10 & 1.390 & 1.385 & 1.394 & 1.392 & 1.405 & 1.402 \\
\hline C10-C11 & 1.393 & 1.392 & 1.390 & 1.388 & 1.389 & 1.388 \\
\hline C11-C6 & 1.406 & 1.403 & 1.408 & 1.405 & 1.407 & 1.404 \\
\hline C9-F & 1.350 & 1.356 & - & - & - & - \\
\hline C9-N & - & - & 1.467 & 1.474 & - & - \\
\hline $\mathrm{N}-\mathrm{O} 1$ & - & - & 1.232 & 1.226 & - & - \\
\hline $\mathrm{N}-\mathrm{O} 2$ & - & - & 1.232 & 1.226 & - & - \\
\hline C9-C & - & - & - & - & 1.433 & 1.430 \\
\hline$C \equiv N$ & - & - & - & - & 1.164 & 1.156 \\
\hline C5-S1-C2 & 91.36 & 91.39 & 91.44 & 91.46 & 91.42 & 91.45 \\
\hline S1-C2-C3 & 112.44 & 112.36 & 112.38 & 112.33 & 112.38 & 112.32 \\
\hline $\mathrm{C} 2-\mathrm{C} 3-\mathrm{C} 4$ & 111.23 & 111.35 & 111.33 & 111.40 & 111.31 & 111.40 \\
\hline C3-C4-C5 & 113.45 & 113.35. & 113.29 & 113.23 & 113.32 & 113.25 \\
\hline C4-C5-S1 & 111.52 & 111.55 & 111.56 & 111.59 & 111.56 & 111.58 \\
\hline $\mathrm{C} 2-\mathrm{C} 3-\mathrm{C} 6$ & 124.53 & 124.43 & 124.32 & 124.27 & 124.35 & 124.29 \\
\hline C4-C3-C6 & 124.23 & 124.22 & 124.35 & 124.33 & 124.33 & 124.31 \\
\hline C7-C6-C3 & 121.16 & 121.11 & 121.09 & 121.04 & 121.14 & 121.11 \\
\hline $\mathrm{C} 11-\mathrm{C} 6-\mathrm{C} 3$ & 120.82 & 120.81 & 120.70 & 120.70 & 120.78 & 120.79 \\
\hline C6-C7-C8 & 121.36 & 121.11 & 121.25 & 121.22 & 121.24 & 121.21 \\
\hline $\mathrm{C} 7-\mathrm{C} 8-\mathrm{C} 9$ & 118.76 & 118.59 & 118.86 & 118.87 & 120.04 & 120.05 \\
\hline C8-C9-C10 & 121.74 & 122.07 & 121.58 & 121.58 & 119.37 & 119.38 \\
\hline C9-C10-C11 & 118.76 & 118.59 & 118.86 & 118.88 & 120.05 & 120.06 \\
\hline C10-C11-C6 & 121.35 & 121.33 & 121.23 & 121.21 & 121.22 & 121.20 \\
\hline C11-C6-C7 & 118.02 & 118.08 & 118.21 & 118.25 & 118.08 & 118.10 \\
\hline C8-C9-F & 119.12 & 118.96 & - & - & - & - \\
\hline C10-C9-F & 119.14 & 118.97 & - & - & - & - \\
\hline C8-C9-N & - & - & 119.20 & 119.21 & - & - \\
\hline C10-C9-N & - & - & 119.21 & 119.21 & - & - \\
\hline C9-N-O1 & - & - & 117.72 & 117.73 & - & - \\
\hline $\mathrm{C} 9-\mathrm{N}-\mathrm{O} 2$ & - & - & 117.73 & 117.73 & - & - \\
\hline C8-C9-C & - & - & - & - & 120.31 & 120.31 \\
\hline C10-C9-C & - & - & - & - & 120.32 & 120.32 \\
\hline C9-C-N & - & - & - & - & 179.98 & 179.98 \\
\hline $\mathrm{C2}-\mathrm{C} 3-\mathrm{C} 6-\mathrm{C} 7$ & 32.50 & 35.73 & 29.50 & 31.55 & 30.06 & 32.59 \\
\hline
\end{tabular}


Table 2 Calculated vibrational frequencies $\left(\mathrm{cm}^{-1}\right)$ for FPT

\begin{tabular}{|c|c|c|}
\hline \multirow[t]{2}{*}{ Assignments } & \multicolumn{2}{|c|}{ FPT } \\
\hline & $6-31 G(d)$ & 6-311++G(d.p) \\
\hline$v(\mathrm{C}-\mathrm{H})$ th & $3273(0.96)$ & $3246(0.67)$ \\
\hline$v(\mathrm{C}-\mathrm{H})$ th & $3269(1.24)$ & $3242(1.02)$ \\
\hline$v(\mathrm{C}-\mathrm{H}) \mathrm{th}, \mathrm{v}(\mathrm{C}-\mathrm{H}) \mathrm{ph}$ & $3226(5.40)$ & $3203(2.29)$ \\
\hline$v(C-H)$ th, v(C-H)ph & $3224(5.98)$ & $3201(2.84)$ \\
\hline$v(C-H) t h, v(C-H) p h$ & $3223(4.14)$ & $3200(2.26)$ \\
\hline$v(C-H)$ th, v(C-H)ph & $3202(6.33)$ & $3180(3.54)$ \\
\hline$v(C-H) p h$ & $3201(9.83)$ & $3179(7.59)$ \\
\hline$v(C-C) p h$ & $1669(25.52)$ & 1645(20.75) \\
\hline v(C-C)ph & $1641(3.02)$ & $1627(3.30)$ \\
\hline$v(C-C) p h, v(C-C)$ th & 1595(16.96) & 1573(20.98) \\
\hline$v(C-C) p h, v(C-C)$ th & 1560(122.96) & 1535(130.98) \\
\hline$v(C-C) p h, v(C-C)$ th & $1475(2.83)$ & $1451(2.32)$ \\
\hline$v(C-C) p h, v(C-C)$ th & $1458(3.50)$ & 1439(3.37) \\
\hline$v(C-C) p h, v(C-C)$ th & 1406(11.87) & 1388(10.73) \\
\hline$v(C-C) p h, \delta(C-H)$ ip-th & $1339(0.63)$ & $1323(2.50)$ \\
\hline$\delta(C-H) i p-t h, \delta(C-H) i p-p h$ & $1328(2.20)$ & 1314(1.01) \\
\hline$v(C-C), v(C-F), \delta(C-H)$ ip-th & $1290(41.22)$ & $1275(2.06)$ \\
\hline$v(C-F), \delta(C-H) i p-t h, \delta(C-H) i p-p h$ & 1283(81.11) & $1241(138.39)$ \\
\hline$\delta(C-H)$ ip-th, $\delta(C-H)$ ip-ph & 1232(9.39) & $1217(7.52)$ \\
\hline$\delta(C-H) i p-p h$ & 1194(17.64) & 1179(34.33) \\
\hline$\delta(C-H)$ ip-ph, $\delta(C-H) i p-t h$ & 1130(8.61) & $1119(8,16)$ \\
\hline$\delta(C-H) i p-t h, \delta(C-H) i p-p h$ & $1122(2.00)$ & 1109(3.73) \\
\hline$\delta(C-H)$ ip-th, $\delta(C-H)$ ip-ph & 1065(1.07) & $1057(1.21)$ \\
\hline a(ring)ph, $\delta(C-H) i p-p h$ & 1034(2.00) & 1030(4.03) \\
\hline$\delta(C-H)$ opp-ph & $959(0.23)$ & $973(0.25)$ \\
\hline$\delta(\mathrm{C}-\mathrm{H}) \mathrm{opp}-\mathrm{ph}$ & $953(0.03)$ & $956(0.09)$ \\
\hline a(ring)th, $\delta(C-H) o p p-t h, a($ ring)ph & $911(8.64)$ & $909(9.70)$ \\
\hline$\delta(\mathrm{C}-\mathrm{H})$ opp-th & $895(0.72)$ & $895(0.60)$ \\
\hline$\delta(\mathrm{C}-\mathrm{H}) \mathrm{opp}-\mathrm{ph}, \mathrm{v}(\mathrm{C}-\mathrm{S}), \delta(\mathrm{C}-\mathrm{H}) \mathrm{opp}-\mathrm{th}$ & $871(26.90)$ & $867(25.59)$ \\
\hline$\delta(\mathrm{C}-\mathrm{H}) \mathrm{opp}-\mathrm{ph}, \delta(\mathrm{C}-\mathrm{H}) \mathrm{opp}$-th & $849(44.62)$ & $851(58.48)$ \\
\hline a(ring)th, $\delta(C-H) o p p-p h, a($ ring)ph & $844(1.46)$ & $835(4.97)$ \\
\hline$\delta(C-H) o p p-p h$ & $831(0.41)$ & $826(0.16)$ \\
\hline $\begin{array}{l}\text { a(ring)th, a(ring)ph, } \delta(C-H) o p p-p h, \\
\delta(C-H) o p p-t h\end{array}$ & $804(7.14)$ & 797(13.20) \\
\hline$\delta(\mathrm{C}-\mathrm{H}) \mathrm{opp}-\mathrm{ph}, \delta(\mathrm{C}-\mathrm{H}) \mathrm{opp}$-th & $793(84.60)$ & $788(82.73)$ \\
\hline$\delta(\mathrm{C}-\mathrm{H})$ opp-ph, $\delta(\mathrm{C}-\mathrm{H})$ opp-th, $\Phi($ ring $)$ ph & $720(3.48)$ & $727(7.80)$ \\
\hline$\delta(C-H)$ opp-ph & 685(1.49) & $687(3.06)$ \\
\hline$\delta(\mathrm{C}-\mathrm{H})$ opp-ph, $\Phi($ ring)ph, $\Phi($ ring)th & $661(5.22)$ & $659(7.52)$ \\
\hline$\Phi($ ring)ph, $\Phi($ ring)th & $645(3.39)$ & $644(3.97)$ \\
\hline$\Phi$ (ring)ph, $\Phi$ (ring)th & $641(1.76)$ & $636(4.69)$ \\
\hline a(ring)th, a(ring)ph & $573(19.72)$ & $573(23.87)$ \\
\hline$\Phi$ (ring)ph, $\Phi($ ring)th, $\delta(C-H)$ opp-ph & $535(8.08)$ & $532(18.09)$ \\
\hline
\end{tabular}

Table 2 Calculated vibrational frequencies $\left(\mathrm{cm}^{-1}\right)$ for FPT (Continued)

\begin{tabular}{lll}
\hline$\Phi($ ring)th & $467(1.03)$ & $468(0.97)$ \\
$\Phi($ ring)ph, $\Phi($ ring)th & $444(0.42)$ & $442(0.69)$ \\
$\Phi($ ring)ph & $426(0.09)$ & $426(0.11)$
\end{tabular}

The numbers in the parentheses correspond to the IR intensities. $a$ : planar ring deformation, $\Phi$ : non-planar deformation, v: stretching, $\delta$ : bending, ph: benzene, th: thiophene.

type (Coffman et al. 1996). The bond angles in the benzene rings $\left(120^{\circ}\right)$ have the value between $118^{\circ}-121^{\circ}$ for all the compounds, which may be result from the $\pi$ delocalization through the whole molecules. For CPT, the value of bond angle C9-C-N is $179.98^{\circ}$.

In all cases, the atoms in the $\mathrm{R}$ group are coplanar with the corresponding benzene ring, which indicates that there are only two planar (thiophene ring and benzene ring) within each of the title compounds. The values of dihedral angles between the thiophene and benzene rings are $29.50^{\circ}-35.73^{\circ}$. The angles calculated at $\mathrm{B} 3 \mathrm{LYP} /$ $6-311++G(d, p)$ level have higher values than that calculated at B3LYP/6-31G(d) level. Nonetheless, the two calculated levels represent the same tendency for the three compounds. FPT has the biggest values of dihedral angle while NPT has the smallest, which indicates that NPT has the highest $\pi$-conjugated structure (Haddon 2001).

\subsection{Vibrational frequency}

Vibrational frequencies were calculated by B3LYP/6-31G (d) and B3LYP/6-311++G(d,p) methods. Tables 2, 3, 4 presents the calculated vibrational frequencies over the range $4000-400 \mathrm{~cm}^{-1}$ of the title compounds studied. Inclusion of electron correlation in density functional theory to a certain extent makes the frequency values closer to the experimental vibrational frequencies. According to the data in Tables 2, 3, 4, the frequencies values calculated with $6-311++G(d, p)$ basis set are smaller than that with 6$31 \mathrm{G}(\mathrm{d})$ basis set. The following discussions are being done with the results at DFT level calculation with $6-311++G$ $(d, p)$ basis set for a higher accuracy. Calculated IR intensities help us to distinguish and more precisely assign those fundamentals which are close in frequency (Li et al. 2011). The theoretical FT-IR spectra calculated at B3LYP/ 6-31G(d) and B3LYP/6-311++G(d,p) levels are shown in Figures 2 and 3, respectively.

\subsubsection{C-H vibrations}

The existence of one or more aromatic rings in a molecule is normally determined from the $\mathrm{C}-\mathrm{H}$ and $\mathrm{C}-\mathrm{C}=\mathrm{C}$ ring related vibrations. The $\mathrm{C}-\mathrm{H}$ stretching occurs above $3000 \mathrm{~cm}^{-1}$ and is typically exhibited as a multiplicity of weak to moderate bands (Hunt et al. 1987). In the present theoretical study, the FTIR band in the region 3300- 
Table 3 Calculated vibrational frequencies $\left(\mathrm{cm}^{-1}\right)$ for NPT

\begin{tabular}{|c|c|c|}
\hline \multirow[t]{2}{*}{ Assignments } & \multicolumn{2}{|c|}{ NPT } \\
\hline & $6-31 G(d)$ & 6-311++G(d.p) \\
\hline$v(C-H)$ th & $3275(0.75)$ & $3248(0.80)$ \\
\hline$v(C-H)$ th & $3271(0.68)$ & $3243(1.01)$ \\
\hline$v(C-H) p h$ & $3252(1.02)$ & $3222(3.22)$ \\
\hline$v(C-H) p h$ & $3251(0.48)$ & $3221(0.75)$ \\
\hline$v(\mathrm{C}-\mathrm{H}) \mathrm{th}, \mathrm{v}(\mathrm{C}-\mathrm{H}) \mathrm{ph}$ & $3230(2.93)$ & $3207(1.42)$ \\
\hline$v(C-H)$ th, v(C-H)ph & $3212(5.72)$ & $3190(3.63)$ \\
\hline$v(C-H) p h$ & $3210(6.44)$ & $3188(3.92)$ \\
\hline$v(\mathrm{C}-\mathrm{C}) \mathrm{ph}, \mathrm{v}(\mathrm{N}-\mathrm{O})$ & 1665(105.58) & $1637(68.31)$ \\
\hline$v(C-C) p h$ & 1655(96.36) & 1635(101.67) \\
\hline$v(\mathrm{C}-\mathrm{C}) \mathrm{ph}, \mathrm{v}(\mathrm{C}-\mathrm{C})$ th, $\mathrm{v}(\mathrm{N}-\mathrm{O})$ & $1611(96.07)$ & 1574(144.85) \\
\hline$v(C-C)$ th & $1588(20.32)$ & 1564(88.76) \\
\hline$v(C-C) p h, v(C-C)$ th & $1541(13.83)$ & 1523(13.80) \\
\hline$v(C-C) p h, v(C-C)$ th & $1475(10.72)$ & $1453(7.25)$ \\
\hline$v(C-C) p h, v(C-C)$ th & $1458(4.38)$ & $1440(3.14)$ \\
\hline$v(C-C) p h, v(C-C)$ th & $1407(5.29)$ & 1389(6.69) \\
\hline$v(C-N)$ & 1393(554.93) & 1363(593.08) \\
\hline$v(C-C) p h$ & $1363(7.22)$ & 1346(10.99) \\
\hline$\delta(C-H)$ ip-ph & $1329(2.98)$ & $1316(5.55)$ \\
\hline$\delta(C-H)$ ip-th, $\delta(C-H)$ ip-ph & $1291(8.10)$ & $1279(7.66)$ \\
\hline$\delta(C-H) i p-t h$ & $1236(9.45)$ & $1221(7.50)$ \\
\hline$\delta(C-H)$ ip-ph & $1218(5.70)$ & $1206(6.98)$ \\
\hline$\delta(C-H)$ ip-ph & $1140(7.72)$ & $1131(8.01)$ \\
\hline$\delta(C-H)$ ip-th, $\delta(C-H)$ ip-ph & $1135(64.27)$ & 1121(78.97) \\
\hline$\delta(C-H) i p-t h$ & $1124(10.75)$ & $1110(18.81)$ \\
\hline a(ring)th, $\delta(C-H)$ ip-th, $\delta(C-H)$ ip-ph & $1065(1.34)$ & $1056(1.01)$ \\
\hline a(ring)ph & $1033(0.61)$ & 1029(1.26) \\
\hline$\delta(C-H) o p p-p h$ & $993(0.66)$ & $998(0.08)$ \\
\hline$\delta(C-H) o p p-p h$ & $983(0.09)$ & $987(0.99)$ \\
\hline a(ring)th & $912(0.88)$ & $910(1.42)$ \\
\hline$\delta(\mathrm{C}-\mathrm{H}) \mathrm{opp}-\mathrm{ph}, \delta(\mathrm{C}-\mathrm{H}) \mathrm{opp}-\mathrm{th}$ & $898(1.60)$ & $898(1.33)$ \\
\hline$\delta(\mathrm{C}-\mathrm{H})$ opp-ph, $\delta(\mathrm{C}-\mathrm{H}) \mathrm{opp}-\mathrm{th}$ & $884(13.61)$ & $879(13.51)$ \\
\hline$\delta(\mathrm{C}-\mathrm{H})$ opp-ph, v(C-S), $\delta(\mathrm{C}-\mathrm{H}) \mathrm{opp}$-th & $870(15.92)$ & $869(44.51)$ \\
\hline $\begin{array}{l}\text { a(ring)th, a(ring)ph, } \delta(C-H) o p p-p h, \\
\delta(C-H) \text { opp-th, } \delta(N-O)\end{array}$ & $862(84.49)$ & $861(72.40)$ \\
\hline$\delta(C-H) o p p-p h$ & $851(4.91)$ & $847(1.69)$ \\
\hline$\delta(\mathrm{C}-\mathrm{H}) \mathrm{opp}-\mathrm{ph}, \mathrm{a}($ ring $)$ th & $817(4.24)$ & $812(1.70)$ \\
\hline $\begin{array}{l}\delta(\mathrm{C}-\mathrm{H}) \text { opp-th, } \delta(\mathrm{C}-\mathrm{H}) \text { opp-ph, } \Phi(\text { ring }) \text { ph, } \\
\Phi(\text { ring)th }\end{array}$ & $802(52.29)$ & $793(68.72)$ \\
\hline $\begin{array}{l}\delta(\mathrm{C}-\mathrm{H}) \text { opp-th, } \delta(\mathrm{C}-\mathrm{H}) \mathrm{opp}-\mathrm{ph}, \Phi(\text { ring }) \text { ph, } \\
\delta(\mathrm{C}-\mathrm{N})\end{array}$ & $760(51.52)$ & $745(35.05)$ \\
\hline a(ring)th, a(ring)ph & $716(0.55)$ & $717(0.25)$ \\
\hline$\Phi$ (ring)ph, $\delta(C-H)$ opp-th & $709(6.11)$ & $703(7.85)$ \\
\hline$\delta(\mathrm{C}-\mathrm{H})$ opp-th & $691(3.68)$ & $691(6.69)$ \\
\hline
\end{tabular}

Table 3 Calculated vibrational frequencies $\left(\mathrm{cm}^{-1}\right)$ for NPT (Continued)

\begin{tabular}{lll}
\hline$\Phi($ ring $)$ ph, $\Phi($ ring)th, $\delta(C-H) o p p-t h$ & $655(4.22)$ & $652(4.30)$ \\
$\Phi($ ring)ph, $\Phi($ ring)th, $\delta(C-H) o p p-t h$ & $639(2.62)$ & $634(5.91)$ \\
$\Phi($ ring)ph, $\Phi($ ring)th & $630(0.14)$ & $630(0.12)$ \\
$\delta(C-N)$ & $540(1.26)$ & $538(1.55)$ \\
$\Phi($ ring $)$ ph & $512(3 / 56)$ & $505(8.19)$ \\
$v\left(\right.$ ph- $\left.\mathrm{NO}_{2}\right)$ & $477(6.27)$ & $473(3.64)$ \\
$\Phi($ ring)th & $462(2.64)$ & $463(3.55)$ \\
$\Phi($ ring $) p h$ & $423(0.05)$ & $420(0.08)$ \\
$\Phi($ ring $)$ ph, $\Phi($ ring)th & $410(0.26)$ & $406(0.20)$
\end{tabular}

The numbers in the parentheses correspond to the IR intensities. a: planar ring deformation, $\Phi$ : non-planar deformation, v: stretching, $\delta$ : bending, ph: benzene, th: thiophene.

$3100 \mathrm{~cm}^{-1}$ are assigned to aryl $\mathrm{C}-\mathrm{H}$ stretching vibrations. The $\mathrm{C}-\mathrm{H}$ in plane bending vibration usually occurs in the region $1400-900 \mathrm{~cm}^{-1}$ and is very useful for characterization purpose (Castillo et al. 2012). For FPT, the calculated frequencies 1323, 1314, 1275, 1241, 1217, $1179,1119,1057,1030 \mathrm{~cm}^{-1}$ at B3LYP/6-311++G(d,p) are assigned to $\mathrm{C}-\mathrm{H}$ in plane bending vibrations, which has similar results for NPT and CPT. The $\mathrm{C}-\mathrm{H}$ out of plane deformations are observed between $1000-500 \mathrm{~cm}^{-1}$ for the three title compounds.

\subsubsection{C-S vibrations}

In our present study, the C-S stretching vibrations are observed at $867 \mathrm{~cm}^{-1}$ for FPT, $869 \mathrm{~cm}^{-1}$ for NPT and $873 \mathrm{~cm}^{-1}$ for CPT, respectively.

\subsection{3 $C=C$ stretching}

The ring carbon-carbon stretching vibrations occur in the region $1650-1400 \mathrm{~cm}^{-1}$. For aromatic six-membered rings, there are two of three bands in this region due to skeletal vibrations, the strongest usually being at about $1500 \mathrm{~cm}^{-1}$ (Li et al. 2011). The aromatic $\mathrm{C}=\mathrm{C}$ stretching is observed at $1645,1573,1535 \mathrm{~cm}^{-1}$ for FPT while the strongest peak is observed at $1535 \mathrm{~cm}^{-1}$. The strongest peaks are observed at $1574 \mathrm{~cm}^{-1}$ and $1647 \mathrm{~cm}^{-1}$ for NPT and CPT, respectively, which may be due to the electronwithdrawing effect by the nitro and cyano groups.

\subsubsection{Ring vibrations}

In benzene, six ring deformation frequencies are observed. Three arise from in-plane bending vibrations, corresponding to $1000-600 \mathrm{~cm}^{-1}$ mode and the remaining three are derived from the out-of-plane bending vibrations, corresponding to $700-400 \mathrm{~cm}^{-1}$ mode of vibrations ( $\mathrm{Li}$ et al. 2011). For FPT, the $\alpha$ (ring) vibrations are observed at 909 , 
Table 4 Calculated vibrational frequencies $\left(\mathrm{cm}^{-1}\right)$ for CPT

\begin{tabular}{|c|c|c|}
\hline \multirow[t]{2}{*}{ Assignments } & \multicolumn{2}{|c|}{ CPT } \\
\hline & $6-31 G(d)$ & 6-311++G(d.p) \\
\hline$v(C-H)$ th & $3275(0.77)$ & $3247(0.75)$ \\
\hline$v(C-H)$ th & $3270(0.85)$ & $3242(1.02)$ \\
\hline$v(C-H) p h, v(C-H)$ th & $3229(3.65)$ & $3206(1.69)$ \\
\hline$v(C-H)$ ph, v(C-H)th & $3223(0.21)$ & $3199(0.08)$ \\
\hline$v(\mathrm{C}-\mathrm{H}) \mathrm{th}, \mathrm{v}(\mathrm{C}-\mathrm{H}) \mathrm{ph}$ & $3221(9.86)$ & $3198(5.73)$ \\
\hline$v(C-H)$ th, v(C-H)ph & $3205(4.14)$ & $3182(2.33)$ \\
\hline$v(C-H) p h$ & $3203(7.33)$ & $3181(5.73)$ \\
\hline$v(C \equiv N)$ & 2345(57.40) & $2328(79.30)$ \\
\hline$v(C-C) p h$ & $1665(57.84)$ & 1647(60.69) \\
\hline$v(C-C) p h, v(C-C)$ th & 1608(5.00) & 1590(3.95) \\
\hline$v(C-C) p h, v(C-C)$ th & 1586(13.12) & $1567(18.50)$ \\
\hline$v(C-C) p h, v(C-C)$ th & 1553(19.22) & 1534(17.38) \\
\hline$v(C-C) p h, v(C-C)$ th & $1475(12.16)$ & $1452(8.34)$ \\
\hline$v(C-C) p h, v(C-C)$ th & 1458(7.78) & $1440(7.27)$ \\
\hline$v(C-C) p h, v(C-C)$ th & 1409(8.58) & 1392(7.99) \\
\hline$\delta(C-H)$ ip-ph & $1344(1.37)$ & $1332(1.43)$ \\
\hline$v(C-C) p h, \delta(C-H)$ ip-th & $1330(2.26)$ & 1309(3.74) \\
\hline$v\left(C_{p h}-C_{t h}\right), \delta(C-H) i p-t h, \delta(C-H) i p-p h$ & 1292(3.60) & $1278(2.78)$ \\
\hline$\delta(C-H)$ ip-th, $\delta(C-H)$ ip-ph, v( $\left.C_{p h}-C N\right)$ & $1240(1.60)$ & $1229(0.75)$ \\
\hline$\delta(C-H)$ ip-th, $\delta(C-H)$ ip-ph & 1235(7.16) & $1220(6.33)$ \\
\hline$\delta(C-H) i p-p h$ & $1213(7.31)$ & 1202(8.18) \\
\hline$\delta(C-H) i p-p h$ & 1149(3.00) & 1138(3.87) \\
\hline$\delta(C-H)$ ip-th & $1124(4.56)$ & $1111(5.71)$ \\
\hline a(ring)th, $\delta(C-H)$ ip-th, $\delta(C-H) i p-p h$ & 1066(1.07) & 1057(1.13) \\
\hline a(ring)ph, $\delta(C-H)$ ip-th, $\delta(C-H) i p-p h$ & 1037(1.17) & 1033(1.85) \\
\hline$\delta(\mathrm{C}-\mathrm{H})$ opp-ph & $979(0.04)$ & $989(0.09)$ \\
\hline$\delta(C-H) o p p-p h$ & $972(0.11)$ & $977(0.17)$ \\
\hline a(ringethth & $911(5.98)$ & $909(7.11)$ \\
\hline$\delta(\mathrm{C}-\mathrm{H}) \mathrm{opp}$-th & $898(0.92)$ & $898(0.89)$ \\
\hline$\delta(C-H) o p p-p h, v(C-S), \delta(C-H) o p p-t h$ & $877(26.43)$ & $873(24.47)$ \\
\hline$\delta(\mathrm{C}-\mathrm{H})$ opp-ph, $\delta(\mathrm{C}-\mathrm{H})$ opp-th, & $859(32.47)$ & $857(45.62)$ \\
\hline$\delta(C-H)$ opp-ph & $854(4.92)$ & $849(2.68)$ \\
\hline $\begin{array}{l}\text { a(ring)th, a(ring)ph, } \delta(C-H) o p p-p h \\
\delta(C-H) o p p-t h\end{array}$ & $827(1.07)$ & $820(0.99)$ \\
\hline$\delta(\mathrm{C}-\mathrm{H}) \mathrm{opp}-\mathrm{ph}, \delta(\mathrm{C}-\mathrm{H}) \mathrm{opp}-\mathrm{th}$ & 797(75.99) & $792(79.51)$ \\
\hline a(ring)th, a(ring)ph, $\delta(C-H) o p p-t h$ & $773(1.57)$ & $771(1.11)$ \\
\hline$\delta(\mathrm{C}-\mathrm{H})$ opp-th, $\Phi($ ring $)$ ph & $742(10.37)$ & $742(12.43)$ \\
\hline$\delta(\mathrm{C}-\mathrm{H}) \mathrm{opp}-\mathrm{th}$ & $690(2.66)$ & $691(4.50)$ \\
\hline$\Phi($ ring $)$ ph, $\Phi($ ring $)$ th, $\delta(C-H)$ opp-th & $666(2.98)$ & $665(4.18)$ \\
\hline $\begin{array}{l}\Phi(\text { ring)ph, } \Phi(\text { ring }) \text { th, } \delta(C-H) o p p-t h \\
\delta(C-H) \text { opp-ph }\end{array}$ & $647(2.79)$ & $640(4.16)$ \\
\hline$\Phi($ ring)th & $638(0.22)$ & $637(1.93)$ \\
\hline$\Phi($ ring $)$ ph, $\delta(\mathrm{C}-\mathrm{H}) \mathrm{opp}-\mathrm{ph}, \delta\left(\mathrm{C}_{\mathrm{ph}}-\mathrm{CN}\right)$ & $574(15.24)$ & $576(15.05)$ \\
\hline$\Phi$ (ring)ph, $\delta(C-H) o p p-p h, \delta\left(C_{p h}-C N\right)$ & $561(1.38)$ & $569(7.44)$ \\
\hline
\end{tabular}

Table 4 Calculated vibrational frequencies $\left(\mathrm{cm}^{-1}\right)$ for CPT (Continued)

\begin{tabular}{lll}
\hline a(ring)ph, a(ring)th & $532(4.37)$ & $532(4.04)$ \\
$\Phi($ ring)th, $\Phi($ ring)ph & $484(0.05)$ & $485(0.59)$ \\
$\Phi($ ring)th & $460(1.73)$ & $461(1.83)$ \\
$\Phi($ ring $)$ ph & $414(0.01)$ & $412(0.01)$ \\
\hline
\end{tabular}

The numbers in the parentheses correspond to the IR intensities. a: planar ring deformation, $\Phi$ : non-planar deformation, v: stretching, $\delta$ : bending, ph: benzene, th: thiophene.

835, 797, $573 \mathrm{~cm}^{-1}$ and $\Phi($ ring) vibrations at 644,636 , $532 \mathrm{~cm}^{-1}$.

\subsection{C-N vibrations}

For NPT, the strong peak at $1363 \mathrm{~cm}^{-1}$ is assigned to the $\mathrm{C}_{\mathrm{ph}}-\mathrm{N}$ single-bonded stretching. For $\mathrm{CPT}$, the $\mathrm{C} \equiv \mathrm{N}$ stretching is observed at $2328 \mathrm{~cm}^{-1}$.

\subsection{6 $\mathrm{N}-\mathrm{O}$ vibrations}

The $\mathrm{N}-\mathrm{O}$ stretching vibration is observed at 1637 and $1574 \mathrm{~cm}^{-1}$ for NPT.

\section{$3.3{ }^{13} \mathrm{C}$ and ${ }^{1} \mathrm{H}$ NMR studies}

The calculated values of ${ }^{13} \mathrm{C}$ and ${ }^{1} \mathrm{H}$ chemical shifts by B3LYP/6-311++G(d,p) method in the gas phase are summarized in Tables 5 and 6.

(Li and Zhang 2013) calculated the ${ }^{13} \mathrm{C}$ and ${ }^{1} \mathrm{H}$ chemical shifts of 2-dicyanovinyl-5-(4- methoxyphenyl) thiophene in the gas phase by B3LYP/6-311++G(d,p) and B3LYP/ $6-311++G(2 d, 2 p)$ method and the calculated results are good agreement with the experimental ones ( $\mathrm{Li}$ and Zhang 2013). In order to have a comparison, we extend our study by employing B3LYP/6-311++G(2d,2p) method to calculated the ${ }^{13} \mathrm{C}$ and ${ }^{1} \mathrm{H}$ chemical shifts in the gas phase. It has been proved that the chemical shifts calculated by $\mathrm{B} 3 \mathrm{LYP} / 6-311++\mathrm{G}(2 \mathrm{~d}, 2 \mathrm{p})$ method are closer to the experimental values than those calculated by B3LYP/ 6-311++G(d,p) method ( $\mathrm{Li}$ et al. 2011). It is noted that all the ${ }^{13} \mathrm{C}$ and ${ }^{1} \mathrm{H}$ chemical shifts are in there normal values for all the compounds. The ${ }^{1} \mathrm{H}$ chemical shifts calculated by B3LYP/6-311++G(2d,2p) method have higher values than those calculated by B3LYP/6-311+ $+\mathrm{G}(\mathrm{d}, \mathrm{p})$ method in the present study. For the thiophene ring, C3 has the highest chemical shifts in each compound, which may due to the substituting effects of the benzene moiety. The $\mathrm{C} 9$ in the benzene rings have the highest value of chemical shifts for FPT and NPT while that of CPT has the smallest, indicating the effect of the substituted groups at $\mathrm{C}$.

\subsection{Mulliken charges}

The atomic charge in the molecules is fundamental to chemistry. Mulliken atomic charges calculated at the 


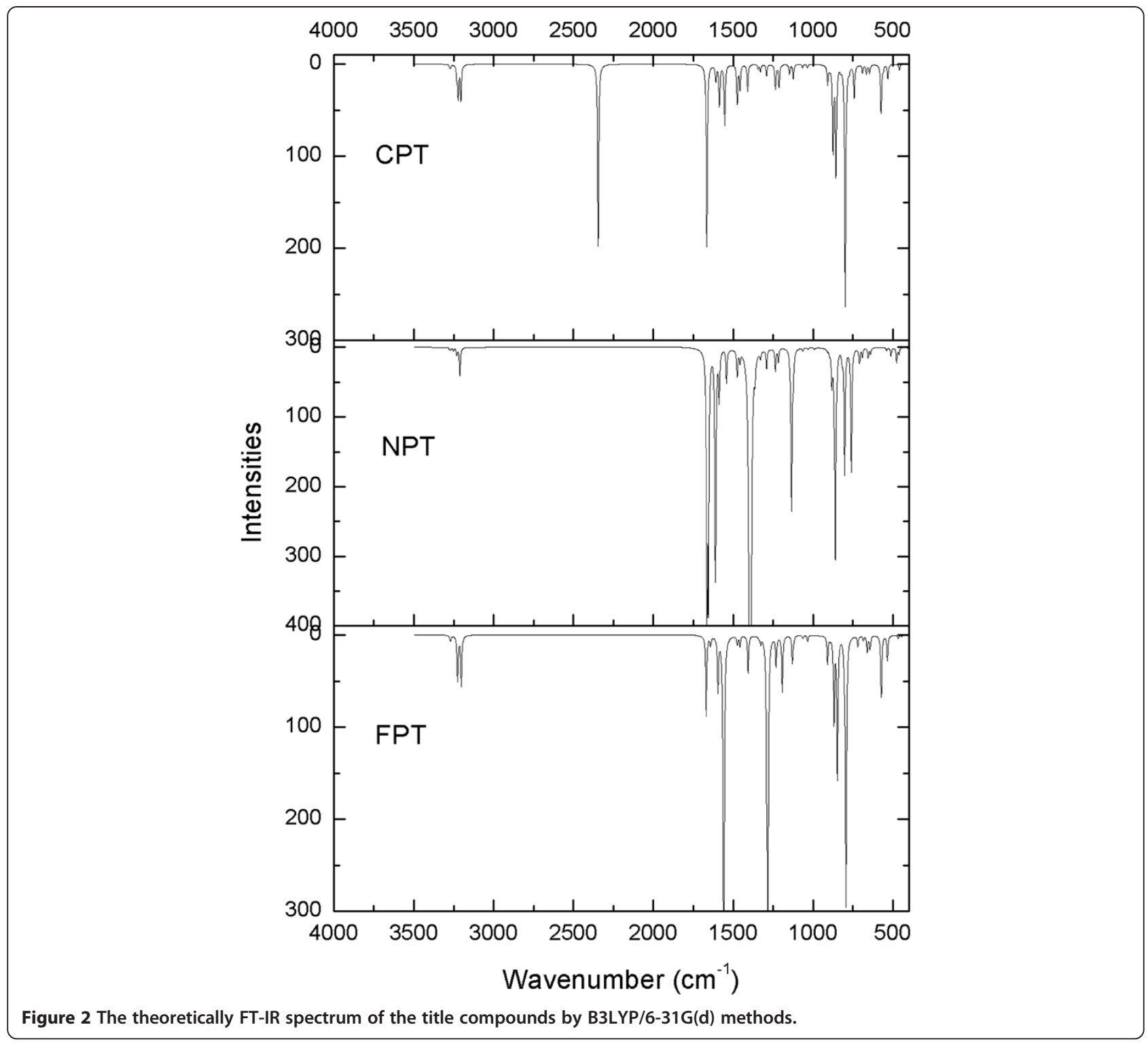

B3LYP/6-311++G(d,p) level are shown in Figure 4. It is noted from Figure 5 that the charge distribution of the aromatic skeleton is related with the substituted groups at C9. For example, the charge of C9 atom is -0.796 for FPT, -0.170 for NPT, and 2.113 for CPT. The sum charges of the substituted groups are -0.173 for FPT, -0.211 for NPT, and -1.82 for CPT, which indicates that cyano group has the highest electron-withdrawing effect. The charge values on $\mathrm{S}$ atom decrease from -0.439 to -0.475 from FPT to CPT. All the hydrogen atoms have a net positive charge.

Particularly, the charges on $\mathrm{H} 2$ and $\mathrm{H} 5$ atoms exhibit large positive values $(0.275$ and 0.265 for FPT, 0.277 and 0.273 for NPT, 0.279 and 0.273 for CPT). The presence of large negative charge on $\mathrm{S}$ atom and positive charge on $\mathrm{H} 2$ or $\mathrm{H} 5$ atom may suggest the formation of intramolecular interactions in the solid states.

\subsection{Electronic spectra}

To the best of our knowledge, no experimental UV-vis spectra of the title compounds is reported. Figure 5 display the calculated spectra of the title compounds at B3LYP/6-311++G(d,p) level. Tables 7, 8, 9 list the excitation energies of the Frontier orbitals and oscillator strengths of the optimized ground state geometries. At the B3LYP/6-311++G(d,p) level of theory the excitation bands of the title compounds are composed of mixed $\mathrm{HOMO}-\mathrm{n} \rightarrow \mathrm{LUMO}+\mathrm{m}$ excitations. Figure 6 compares contour plots of three highest occupied and three lowest 


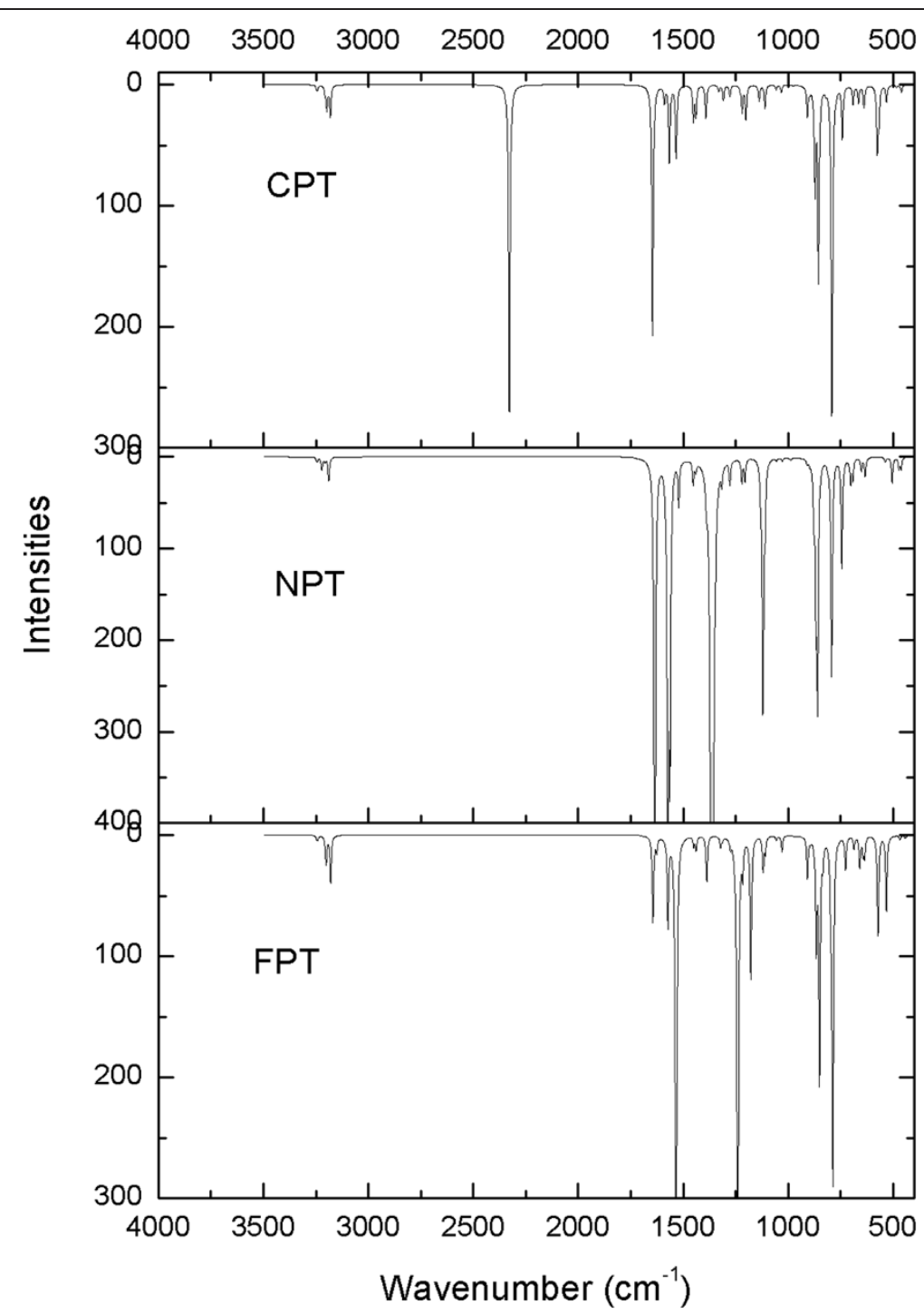

Figure 3 The theoretically FT-IR spectrum of the title compounds by B3LYP/6-311++G(d,p) methods.

Table 5 Calculated $\delta$ (cal) ${ }^{13} \mathrm{C}$ chemical shifts of the title compounds

\begin{tabular}{|c|c|c|c|c|c|c|}
\hline \multirow[t]{2}{*}{$\mathrm{C}$} & \multicolumn{2}{|c|}{ FPT } & \multicolumn{2}{|c|}{ NPT } & \multicolumn{2}{|c|}{ CPT } \\
\hline & $6-311++G(d, p)$ & $6-311++G(2 d, 2 p)$ & $6-311++G(d, p)$ & $6-311++G(2 d, 2 p)$ & $6-311++G(d, p)$ & $6-311++G(2 d, 2 p)$ \\
\hline 2 & 130.4 & 129.8 & 133.9 & 133.0 & 132.9 & 132.2 \\
\hline 3 & 148.1 & 148.9 & 146.7 & 147.6 & 147.1 & 148.0 \\
\hline 4 & 130.5 & 131.1 & 130.1 & 130.7 & 130.0 & 130.6 \\
\hline 5 & 136.2 & 136.1 & 137.2 & 137.3 & 137.1 & 137.1 \\
\hline 6 & 139.4 & 139.7 & 149.0 & 149.4 & 146.4 & 146.9 \\
\hline 7 & 133.2 & 133.2 & 130.6 & 130.8 & 131.2 & 131.1 \\
\hline 8 & 120.1 & 120.2 & 129.6 & 130.3 & 138.9 & 138.8 \\
\hline 9 & 171.1 & 171.6 & 153.1 & 153.6 & 115.9 & 116.4 \\
\hline 10 & 119.8 & 119.9 & 129.6 & 130.1 & 138.8 & 138.7 \\
\hline 11 & 133.0 & 133.0 & 130.5 & 130.8 & 131.2 & 131.1 \\
\hline $12^{\mathrm{a}}$ & - & - & - & & 122.1 & 122.9 \\
\hline
\end{tabular}

${ }^{\mathrm{a}} \mathrm{C}$ atom in cyano group for CPT. 
Table 6 Calculated $\delta$ (cal) ${ }^{13} \mathrm{H}$ chemical shifts of the title compounds

\begin{tabular}{|c|c|c|c|c|c|c|}
\hline \multirow[t]{2}{*}{$\overline{\mathrm{H}^{\mathrm{a}}}$} & \multicolumn{2}{|c|}{ FPT } & \multicolumn{2}{|c|}{ NPT } & \multicolumn{2}{|c|}{ CPT } \\
\hline & $6-311++G(d, p)$ & $6-311++G(2 d, 2 p)$ & $6-311++G(d, p)$ & $6-311++G(2 d, 2 p)$ & $6-311++G(d, p)$ & $6-311++G(2 d, 2 p)$ \\
\hline 2 & 7.29 & 7.63 & 7.57 & 7.92 & 7.50 & 7.85 \\
\hline 4 & 7.30 & 7.56 & 7.38 & 7.67 & 7.40 & 7.66 \\
\hline 5 & 7.27 & 7.68 & 7.36 & 7.78 & 7.33 & 7.75 \\
\hline 7 & 7.62 & 7.90 & 7.67 & 8.00 & 7.69 & 8.00 \\
\hline 8 & 7.19 & 7.48 & 8.48 & 8.94 & 7.76 & 8.06 \\
\hline 10 & 7.19 & 7.49 & 8.49 & 8.94 & 7.77 & 8.08 \\
\hline 11 & 7.54 & 7.84 & 7.57 & 7.93 & 7.62 & 7.94 \\
\hline
\end{tabular}

${ }^{\mathrm{a}}$ The number of $\mathrm{H}$ are according to the number of the bonded carbon.

unoccupied molecular orbitals $(\mathrm{H}-2$ to $\mathrm{H}, \mathrm{L}$ to $\mathrm{L}+2$; isovalue $0.02 \mathrm{e} / \mathrm{a} \cdot \mathrm{u}^{3}$ ) that give rise to the transitions.

(4-fluorophenyl)thiophene (FPT) The S1-S5 bands of FPT are calculated at 265, 257, 243, 231, $229 \mathrm{~nm}$. The nature of the strongest absorption band $257 \mathrm{~nm}(\mathrm{~S} 0 \rightarrow \mathrm{S} 2)$ is dominated by excitations from HOMO- $2 \rightarrow \mathrm{LUMO}+0$, $\mathrm{HOMO}-0 \rightarrow \mathrm{LUMO}+0$, and $\mathrm{HOMO}-0 \rightarrow \mathrm{LUMO}+1$, which consist of $n \rightarrow \pi^{*}$ and $\pi \rightarrow \pi^{*}$ transitions (see Frontier orbitals in Figure 6). The oscillator strength of $\mathrm{S} 0 \rightarrow$
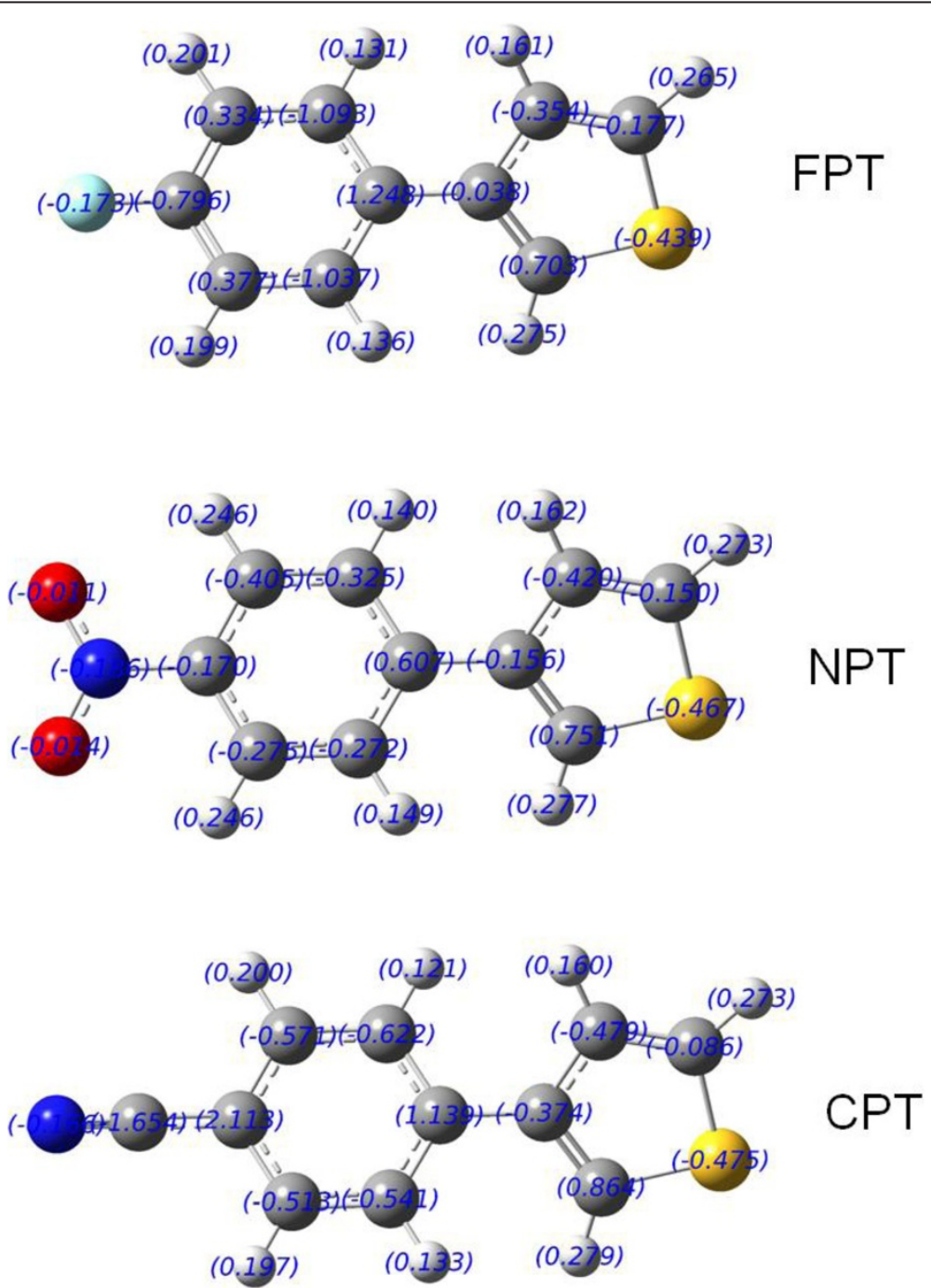

Figure 4 Atomic charges for optimized geometries of the title compounds at B3LYP/6-311++G(d,p) level. 


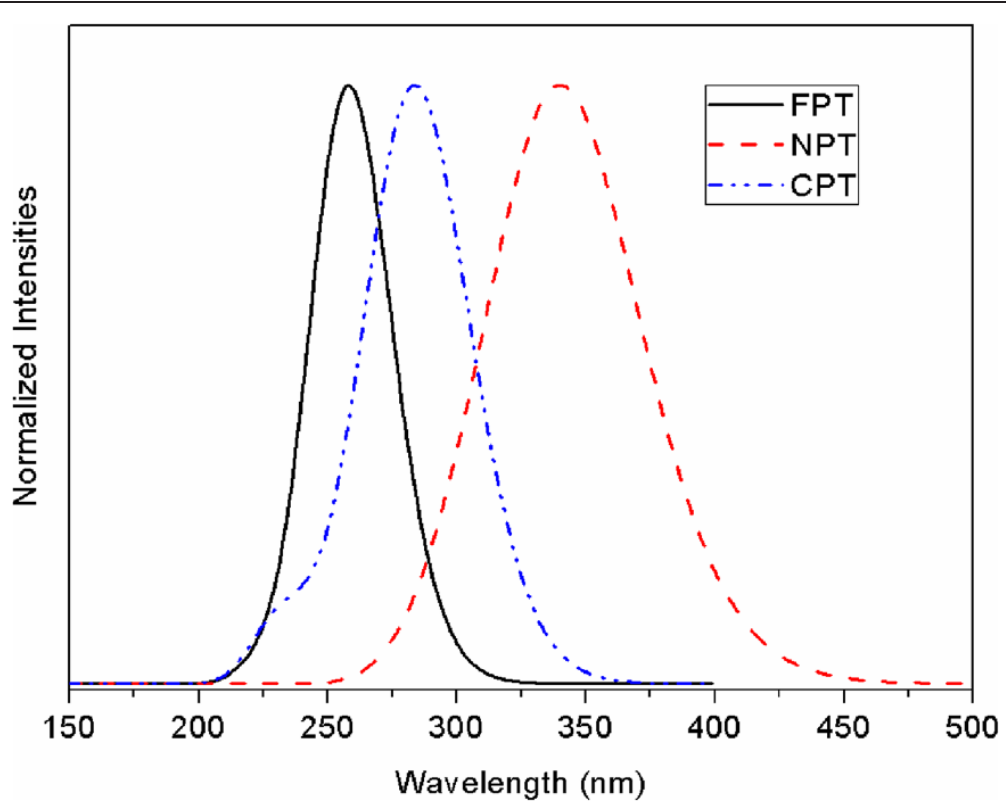

Figure 5 Predicted UV-vis spectra of the title compounds at B3LYP/6-311++G(d,p) level.

S1 band is $f=0.0383$, and the major excitation is HOMO$0 \rightarrow \mathrm{LUMO}+1(62 \%)$, which is assigned to the $\mathrm{n} \rightarrow \pi^{*}$ transition. The HOMO-LUMO gap is calculated to be $5.14 \mathrm{eV}$.

(4-nitrophenyl)thiophene (NPT) The S1-S5 bands of NPT are calculated at 344, 329, 310, 290, $288 \mathrm{~nm}$, which shows red-shifted character compared with FPT. The nature of the strongest absorption band $344 \mathrm{~nm}(\mathrm{~S} 0 \rightarrow \mathrm{S} 1)$ is dominated by excitations from $\mathrm{HOMO}-0 \rightarrow \mathrm{LUMO}+0$ (94\%), which consist of $\pi \rightarrow \pi^{*}$ transitions (see Frontier orbitals in Figure 6). The HOMO-LUMO gap is calculated to be $3.961 \mathrm{eV}$, which is lower than that of FPT. It is reported that the molecules with nitro group can lower the band gaps, which has potential use in photovoltaic cells (Mikroyannidis et al. 2009).

(4-cyanophenyl)thiophene (CPT)) The S1-S5 bands of CPT are calculated at 287, 268, 265, 237, 232 nm, which shows red-shifted character compared with FPT, and blue-shift compared with NPT. The nature of the strongest absorption band $287 \mathrm{~nm}(\mathrm{~S} 0 \rightarrow \mathrm{S} 1)$ is dominated by excitations from HOMO-0 $\rightarrow$ LUMO + 0(96\%), which consist of $n \rightarrow \pi^{*}$ and $\pi \rightarrow \pi^{*}$ transitions (see Frontier orbitals in Figure 6). The HOMO-LUMO gap is calculated to be $4.651 \mathrm{eV}$, which has the intermediate value among the three compounds.

\section{Conclusions}

In the present work, the optimized molecular structures, vibrational frequencies, NMR chemical shifts, and electronic properties of the three title compounds have been calculated by using B3LYP/6-31G(d), B3LYP/6-311++G $(\mathrm{d}, \mathrm{p})$ and TD-B3LYP/6-311++G(d,p) methods. The optimized geometries results show that FPT has the biggest values of dihedral angle while NPT has the smallest, which indicates that NPT has the highest $\pi$-conjugated structure. The vibrational frequencies values calculated

Table 7 B3LYP/6-311++G(d,p) wavelength, excitation energies, and the oscillator strengths for FPT

\begin{tabular}{lllll}
\hline State & FPT & & & \\
\cline { 2 - 4 } & $\boldsymbol{\lambda}(\mathbf{n m})$ & $\mathrm{eV}$ & $\boldsymbol{f}$ & \% contribution \\
\hline S1 & 265.61 & 4.668 & 0.0383 & $\mathrm{H}-2 \rightarrow \mathrm{L}+0(7 \%), \mathrm{H}-0 \rightarrow \mathrm{L}+0(27 \%), \mathrm{H}-0 \rightarrow \mathrm{L}+1(62 \%)$ \\
S2 & 257.41 & 4.817 & 0.2603 & $\mathrm{H}-2 \rightarrow \mathrm{L}+0(3 \%), \mathrm{H}-0 \rightarrow \mathrm{L}+0(68 \%), \mathrm{H}-0 \rightarrow \mathrm{L}+1(24 \%)$ \\
S3 & 243.84 & 0.0002 & $\mathrm{H}-1 \rightarrow \mathrm{L}+0(50 \%), \mathrm{H}-0 \rightarrow \mathrm{L}+2(45 \%)$ \\
S4 & 231.98 & 5.345 & 0.0070 & $\mathrm{H}-1 \rightarrow \mathrm{L}+0(5 \%), \mathrm{H}-0 \rightarrow \mathrm{L}+2(3 \%), \mathrm{H}-0 \rightarrow \mathrm{L}+3(78 \%)$ \\
& & & $\mathrm{H}-0 \rightarrow \mathrm{L}+4(8 \%)$ \\
S5 & 229.23 & 5.409 & $\mathrm{H}-2 \rightarrow \mathrm{L}+0(8 \%), \mathrm{H}-1 \rightarrow \mathrm{L}+1(81 \%), \mathrm{H}-0 \rightarrow \mathrm{L}+3(4 \%)$ \\
\hline
\end{tabular}


Table 8 B3LYP/6-311++G(d,p) wavelength, excitation energies, and the oscillator strengths for NPT

\begin{tabular}{lllll}
\hline State & NPT & & & \\
\cline { 2 - 4 } & $\boldsymbol{\lambda}(\mathbf{n m})$ & $\mathrm{eV}$ & $\boldsymbol{f}$ & \% contribution \\
\hline S1 & 344.39 & 3.600 & 0.3120 & $\mathrm{H}-3 \rightarrow \mathrm{L}+0(2 \%), \mathrm{H}-0 \rightarrow \mathrm{L}+0(96 \%)$ \\
$\mathrm{S} 2$ & 329.99 & 3.757 & 0.0085 & $\mathrm{H}-3 \rightarrow \mathrm{L}+0(91 \%), \mathrm{H}-3 \rightarrow \mathrm{L}+1(2 \%), \mathrm{H}-0 \rightarrow \mathrm{L}+0(2 \%)$ \\
$\mathrm{S} 3$ & 310.18 & 3.997 & 0.0793 & $\mathrm{H}-1 \rightarrow \mathrm{L}+0(98 \%)$ \\
S4 & 290.03 & 4.275 & 0.0077 & $\mathrm{H}-5 \rightarrow \mathrm{L}+0(29 \%), \mathrm{H}-2 \rightarrow \mathrm{L}+0(61 \%), \mathrm{H}-0 \rightarrow \mathrm{L}+1(2 \%)$ \\
& & & $\mathrm{H}-0 \rightarrow \mathrm{L}+2(4 \%)$ \\
$\mathrm{S} 5$ & 288.72 & 4.294 & 0.0042 & $\mathrm{H}-5 \rightarrow \mathrm{L}+0(66 \%), \mathrm{H}-2 \rightarrow \mathrm{L}+0(27 \%)$ \\
\hline
\end{tabular}

Table 9 B3LYP/6-311++G(d,p) wavelength, excitation energies, and the oscillator strengths for CPT

\begin{tabular}{|c|c|c|c|c|}
\hline \multirow[t]{2}{*}{ State } & \multicolumn{4}{|l|}{ CPT } \\
\hline & $\lambda(\mathrm{nm})$ & $\mathrm{eV}$ & $f$ & $\%$ contribution \\
\hline$\overline{S 1}$ & 287.11 & 4.318 & 0.4520 & $\mathrm{H}-0 \rightarrow \mathrm{L}+\mathrm{O}(94 \%)$ \\
\hline S2 & 268.77 & 4.613 & 0.0590 & $\mathrm{H}-2 \rightarrow \mathrm{L}+\mathrm{O}(10 \%), \mathrm{H}-1 \rightarrow \mathrm{L}+\mathrm{O}(55 \%), \mathrm{H}-\mathrm{O} \rightarrow \mathrm{L}+1(33 \%)$ \\
\hline \multirow[t]{2}{*}{ S3 } & 265.04 & 4.678 & 0.0735 & $\mathrm{H}-2 \rightarrow \mathrm{L}+\mathrm{O}(20 \%), \mathrm{H}-1 \rightarrow \mathrm{L}+\mathrm{O}(38 \%), \mathrm{H}-0 \rightarrow \mathrm{L}+1(34 \%)$ \\
\hline & & & & $\mathrm{H}-0 \rightarrow \mathrm{L}+2(6 \%)$ \\
\hline \multirow[t]{3}{*}{ S4 } & 237.49 & 5.220 & 0.0137 & $H-3 \rightarrow L+0(5 \%), H-3 \rightarrow L+1(2 \%), H-2 \rightarrow L+0(21 \%)$ \\
\hline & & & & $\mathrm{H}-1 \rightarrow \mathrm{L}+\mathrm{O}(3 \%), \mathrm{H}-1 \rightarrow \mathrm{L}+1(3 \%), \mathrm{H}-1 \rightarrow \mathrm{L}+2(2 \%)$ \\
\hline & & & & $\mathrm{H}-\mathrm{O} \rightarrow \mathrm{L}+1(20 \%), \mathrm{H}-0 \rightarrow \mathrm{L}+2(40 \%)$ \\
\hline \multirow[t]{2}{*}{ S5 } & 232.34 & 5.34 & 0.0512 & $H-3 \rightarrow L+0(6 \%), H-3 \rightarrow L+1(4 \%), H-2 \rightarrow L+0(13 \%)$ \\
\hline & & & & $\mathrm{H}-1 \rightarrow \mathrm{L}+1(40 \%), \mathrm{H}-0 \rightarrow \mathrm{L}+1(5 \%), \mathrm{H}-0 \rightarrow \mathrm{L}+2(29 \%)$ \\
\hline
\end{tabular}
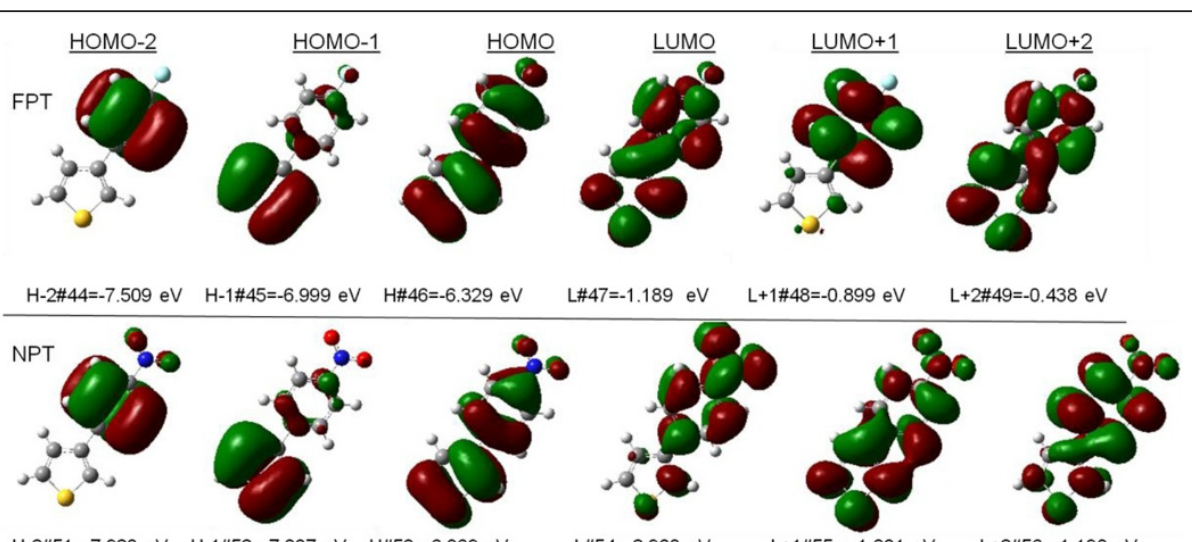

$H-2 \# 51=-7.928 \mathrm{eV} \quad H-1 \# 52=-7.387 \mathrm{eV} \quad H \# 53=-6.869 \mathrm{eV} \quad L \# 54=-2.908 \mathrm{eV} \quad L+1 \# 55=-1.381 \mathrm{eV} \quad L+2 \# 56=-1.198 \mathrm{eV}$

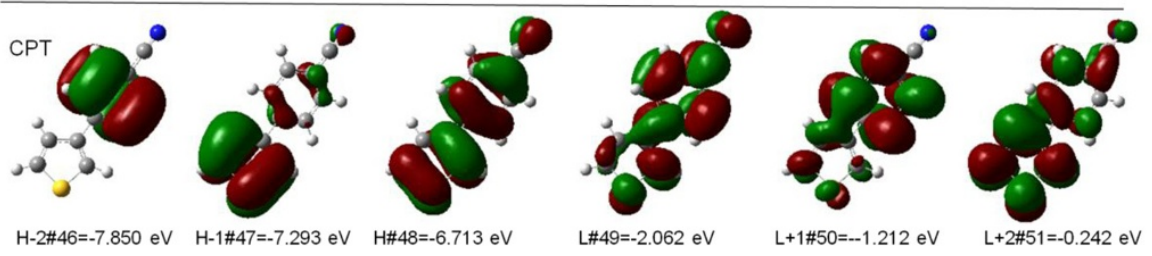

Figure 6 Frontier molecular orbitals of FPT, NPT and CPT calculated at B3LYP/6-311++G(d,p)//TD- B3LYP/6-311++G(d,p). 
with $6-311++G(d, p)$ basis set are smaller than that with 6-31G(d) basis set for all the compounds. For NPT, the strong peak at $1363 \mathrm{~cm}^{-1}$ is assigned to the $\mathrm{C}_{\mathrm{ph}}-\mathrm{N}$ single-bonded stretching, and the N-O stretching vibration is observed at 1637 and $1574 \mathrm{~cm}^{-1}$. For CPT, the $\mathrm{C} \equiv \mathrm{N}$ stretching is observed at $2328 \mathrm{~cm}^{-1}$. The $\mathrm{C} 9$ in the benzene rings have the highest value of chemical shifts for FPT and NPT while that of CPT has the smallest, indicating the effect of the substituted groups at C9. CPT shows red-shifted character compared with FPT, and blue-shift compared with NPT in the TD-DFT calculations. In a word, the type of substituted groups at the $\mathrm{C} 9$ atom have significant effect on the properties for the 3-(4-phenyl)thiophene derivatives. Poly(3-phenylthiophene) has been used reported for used in supercapacitors. The polymerization of the three title compounds are being studied by our group. We believe that the three title compounds will show good performance in supercapacitors.

\section{Competing interests}

The authors declare that they have no competing interests.

\section{Authors' contributions}

YMR carried out literature review, performed the theory analyses and draft the manuscript. SY and XYJ participated in helped to draft the manuscript. All authors read and approved the final manuscript.

\section{Acknowledgments}

This work was supported financially by the Shenzhen Science and Technology Plan Projects (JCYJ20140419122040611, SGLH20131010153555326, ZDSY20120619141659791).

Received: 28 August 2014 Accepted: 18 November 2014 Published: 28 November 2014

\section{References}

Balaji G, Kale TS, Keerthi A, Della Pelle AM, Thayumanavan S, Valiyaveettil S (2011) Low band gap thiophene-perylene diimide systems with tunable charge transport properties. Org Lett 13(1):18-21, doi:10.1021/ol1023486

Cao YM, Bai Y, Yu QJ, Cheng YM, Liu S, Shi D, Gao FF, Wang P (2009) Dye-sensitized solar cells with a high absorptivity ruthenium sensitizer featuring a 2-(hexylthio) thiophene conjugated bipyridine. J Phys Chem C 113(15):6290-6297, doi:10.1021/jp9006872

Castillo MV, Romano E, Raschi AB, Yurquina A, Brandan SA (2012) Structural study and vibrational spectra of 3-amino-2(4-chlorophenyl) quinazolin-4(3H)-one. Comput Theor Chem 995:43-48, doi:10.1016/j.comptc.2012.06.029

Cho E, Risko C, Kim D, Gysel R, Miller NC, Breiby DW, McGehee MD, Toney MF, Kline RJ, Bredas JL (2012) Three-dimensional packing structure and electronic properties of biaxially oriented poly(2,5-bis(3-alkylthiophene-2-y)thieno[3,2-b]thiophene) films. J Am Chem Soc 134(14):6177-6190, doi:10.1021/ ja210272z

Cicoira F, Santato C, Melucci M, Favaretto L, Gazzano M, Muccini M, Barbarella G (2006) Organic light-emitting transistors based on solution-cast and vacuum-sublimed films of a rigid core thiophene oligomer. Adv Mater 18(2):168-170, doi:10.1002/ adma.200501639

Coffman FL, Cao R, Pianetta PA, Kapoor S, Kelly M, Terminello $\sqcup$ (1996) Near-edge $x$-ray absorption of carbon materials for determining bond hybridization in mixed sp2/sp3 bonded materials. Appl Phys Lett 69:568-570, http://dx.doi.org/ $10.1063 / 1.117789$

Dai CA, Yen WC, Lee YH, Ho CC, Su WF (2007) Facile synthesis of well-defined block copolymers containing regioregular poly(3-hexylthiophene) via anionic macroinitiation method and their self-assembly behavior. J Am Chem Soc 129(36):11036-11037, doi:10.1021/ja0733991

El-Azhary AA, Suter HU (1996) Comparison between optimized geometries and vibrational frequencies calculated by the DFT methods. J Phys Chem 100(37):15056-15063, doi:10.1021/jp9606180
Gaussian 09, Revision D.01, Frisch MJ, Trucks GW, Schlegel HB, Scuseria GE, Robb MA, Cheeseman JR, Scalmani G, Barone V, Mennucci B, Petersson GA, Nakatsuji H, Caricato M, Li X, Hratchian HP, Izmaylov AF, Bloino J, Zheng G, Sonnenberg JL, Hada M, Ehara M, Toyota K, Fukuda R, Hasegawa J, Ishida M, Nakajima T, Honda Y, Kitao O, Nakai H, Vreven T et al (2009) Gaussian 09, Revision B.01. Gaussian, Inc, Wallingford CT

Giovanna B, Manuela M, Giovanna S (2005) The versatile thiophene: An overview of recent research on thiophene-based materials. Adv Mater 17(13):1581-1593, doi:10.1002/adma.200402020

Haddon RC (2001) Comment on the relationship of the pyramidalization angle at a conjugated carbon atom to the sigma bond angles. J Phys Chem A 105(16):4164-4165, doi:10.1021/jp010023f

Hara K, Kurashige M, Dan-oh Y, Kasada C, Shinpo A, Suga S, Sayama K, Arakawa H (2003) Design of new coumarin dyes having thiophene moieties for highly efficient organic-dye-sensitized solar cells. New J Chem 27:783-785, doi:10.1039/B300694H

Hunt JH, Guyot-Sionnest P, Shen YR (1987) Observaiton of C-H stretch vibration of monolayers of molecules: optical sum-frequency generation. Chem Phys Lett 133(3):189-192, doi:10.1016/0009-2614(87)87049-5

Ikawa S, Whalley E (1996) Polarized and depolarized Raman spectra of liquid carbon disulfide in the pressure range 0-10 kbar. I. Vibration frequencies, C-S bond length, and Fermi resonance. J Chem Phys 85:2538-2547, http://dx.doi. org/10.1063/1.451061

Jacquemin D, Wathelet V, Perpete EA, Adamo C (2009) Extensive TD-DFT benchmark: Singlet-excited states of organic molecules. J Chem Theo Comput 5(9):2420-2435, doi:10.1021/ct900298e

Karthikeyan G, Sahoo S, Nayak GC, Das CK (2012) Investigagion on doping of poly(3-methyl-thiophene) composites for supercapacitor applications. Macromolecular Res 20(4):351-357, doi:10.1007/s13233-012-0020-7

Kim Y, Cook S, Tuladhar SM, Choulis SA, Nelson J, Durrant JR, Bradley DDC, Glies M, Mcculloch I, Ha CS (2006) A strong regioregularity effect in self-organizing conjugated polymer films and high-efficiency polythiophene: fullerene solar cells. Nature Mater 5:197-203, doi:10.1038/nmat1574

Kline RJ, Mcgehee MD, Toney MF (2006) Highly oriented crystals at the buried interface in polythiophene thin-film transistors. Nature Mater 5:222-228, doi:10.1038/nmat1590

Li XH, Zhang XZ (2013) The spectroscopic, NMR analysis of 2-dicyanovinyl-5(4- methoxyphenyl)thiophene by density functional method. Spectrochim Acta A 105:280-287, doi:10.1016/j.saa.2012.12.048

Li XH, Liu XR, Zhang XZ (2011) Calculation of vibrational spectroscopic and NMR parameters of 2-dicyanovinyl-5-(4-N, N-dimethylaminophenyl)thiophene by ab initio HF and density functional methods. Comput Theor Chem 969(1-3):27-34, doi:10.1016/j.comptc.2011.05.010

Lim JM, Kwon JY, Xu F, Kim HU, Hwang DH, Nanosci J (2013) Pure red phosphorescent organic light-emitting diodes made of iridium(III) complex with thiophene-quinoline ligand. Nanaotech 13(12):8007-8010, PMID:24266181

Lu LL, Hu H, Hou H, Wang BS (2013) An improved B3LYP method in the calculation of organic thermochemistry and reactivity. Comput Theor Chem 1015:64-71, doi:10.1016/j.comptc.2013.04.009

Margules L, Demaison J, Boggs JE (1999) Equilibrium C-F bond length and the structure of formyl fluoride, difluorocarbene, monofluoromethylene, and difluoromethane. J Phys Chem A 103(38):7632-7638, doi:10.1021/jp991417y

Marsh HS, Jankowski E, Jayaraman A (2014) Controlling the morphology of model conjugated thiophene oligomers through alkyl side chain length, placement, and interactions. Macromolecules 47(8):2736-2747, doi:10.1021/ ma5000267

Mikroyannidis JA, Stylianakis MM, Suresh P, Balraju P, Sharma GD (2009) Low band gap vinylene compounds with triphenylamine and benzothiadiazole segments for use in photovoltaic cells. Org Electron 10(7):1320-1333, doi:10.1016/j.orgel.2009.07.013

Mushrush M, Facchetti A, Lefenfeld M, Katz HE, Marks TJ (2003) Easily processable phenylene-thiophene-based organic field-effect transistors and solutionfabricated nonvolatile transistor memory elements. J Am Chem Soc 125(31):9414-9423. doi:10.1021/ja035143a

Osaka T, Komaba S, Fujihana K, Okamoto N, Momma T, Kaneko N (1997) Organic electroluminescence device based on an electrodeposited poly(3-substituted thiophene) film. J Electrochem Soc 144(2):742-448, doi:10.1149/1.1837478

Osaka I, Sauve G, Zhang R, Kowalewski T, McCullough RD (2007) Novel thiophene-thiazolothiazole copolymers for organic field-effect transistors. Adv Mater 19(23):4160-4165, doi:10.1002/adma.200701058 
Patil AV, Lee WH, Lee E, Kim K, Kang IN, Lee SH (2011) Synthesis and photovoltaic properties of a low-band-gap copolymer of dithieno[3,2-2',3'-d]thiophene and dithienylquinoxaline. Macromolecules 44(6):1238-1241, doi:10.1021/ ma102722d

Patra SK, Ahmed R, Whittell GR, Lunn DJ, Dunphy EL, Winnik MA, Manners I (2011) Cylindrical micelles of controlled length with a r-conjugated polythiophene core via crystallization-driven self-assenbly. J Am Chem Soc 133(23):8842-8845, doi:10.1021/ja202408w

Shen L, Xu JK, Wei ZH, Xiao Q, Pu SZ (2005) Electrosynthesis of freestanding poly (3-(4-fluorophenyl)thiophene) films in boron trifluoride diethyl etherate. Eur Polym J 41(8):1738-1746, doi:10.1016/j.eurpolymj.2005.02.027

Sivaraman P, Bhattacharrya AR, Mishra SP, Thakur AP, Shashidhara K, Samui AB (2013) Asymmetric supercapacitor containing poly(3-methyl thiophene)multiwalled carbon nanotubes nanocomposites and activated carbon. Electrochim Acta 94:182-191, doi:10.1016/j.electacta.2013.01.123

Su YZ, Lin JT, Tao YT, Ko CW, Lin SC, Sun SS (2002) Amorphous 2,3-substituted thiophenes: Potential electroluminescent materials. Chem Mater 14:1884-1890, doi:10.1021/cm011671e

Thomas KRJ, Hsu YC, Lin JT, Lee KM, Ho KC, Lai CH, Cheng YM, Chou PT (2008) 2,3-disubstituted thiophene-based organic dyes for solar cells. Chem Mater 20(5):1830-1840, doi:10.1021/cm702631r

Ustamehmetoglu B (2014) Synthesis and characterization of thiophene and thiazole containing polymers. Electrochim Acta 122:130-140, doi:10.1016/j. electacta.2013.12.130

Wei ZH, Xu JK, Hou J, Zhou WQ, Pu SZ (2006) Electrochemical and spectroscopic characteristics of copolymers electrochemically synthesized from 3-(4-fluorophenyl) thiophene and 3,4-ethylenedioxythiophene. J Mater Sci 41(12):3923-3930, doi:10.1007/s10853-005-5505-8

Wolff SK, Ziegler T (1998) Calculation of DFT-GIAO NMR shifts with the inclusion of spin-orbit coupling. J Chem Phys 109:895-905, http://dx.doi.org/10.1063/ 1.476630

Yanai T, Tew DP, Handy NC (2004) A new hybrid exchange-correlation functional using the Coulomb-attenuating method (CAM-B3LYP). Chem Phys Lett 393(1-3):51-57, doi:10.1016/j.cplett.2004.06.011

Yang HC, Shin TJ, Yang L, Cho K, Ryu CY, Bao ZN (2005) Effect of mesoscale crystalline structure on the filed-effect mobility of regioregular poly(3-hexylthiophene) in thin film transistors. Adv Funct Mater 15(4):671-676, doi:10.1002/adfm.200400297

Yue BB, Wang CY, Wagner P, Yang Y, Ding X, Officer DL, Wallace GG (2012) Electrodeposition of pyrrole and 3-(4-tert-butylphenyl)thiophene copolymer for supercapacitos applications. Synthetic Metal 162(24):2216-2221, doi:10.1016/j.synthmet.2012.09.024

Yumura T, Yamashita H (2014) Modulating the electronic properties of multimeric thiophene oligomers by utilizing carbon nanotube confinement. J Phys Chem C 118(10):5510-5522, doi:10.1021/jp5006555

Zhang ZP, Shi GQ (2004) Electrochemical polymerization of 3-phenylthiophene. J Electroanalytical Chem 569(2):197-202, doi:10.1016/j.jelechem.2004.03.001

Zhang QL, Cirpan A, Russell TP, Emrick T (2009) Donor-acceptor poly(thiopheneblock-perylene diimide) copolymers: synthesis and solar cell fabrication. Macromolecules 42(4):1079-1082, doi:10.1021/ma801504e

Zhang F, Wu DQ, Xu YY, Feng XL (2011) Thiophene-based conjugated oligomers for organic solar cells. J Mater Chem 21:17590-17600, doi:10.1039/ C1JM12801A

doi:10.1186/2193-1801-3-701

Cite this article as: Mei-Rong et al:: Vibrational spectroscopic, NMR parameters and electronic properties of three 3-phenylthiophene derivatives via density functional theory. SpringerPlus 2014 3:701.

\section{Submit your manuscript to a SpringerOpen ${ }^{\circ}$ journal and benefit from:}

- Convenient online submission

- Rigorous peer review

- Immediate publication on acceptance

- Open access: articles freely available online

- High visibility within the field

- Retaining the copyright to your article

Submit your next manuscript at $\gg$ springeropen.com 